\title{
KOMUNITAS
}

Jurnal Pengembangan Masyarakat Islam

Vol. 10, No. 2, Desember 2019

\section{Pengembangan Industri Kreatif Berbasis Media Digital di Surabaya dalam Perspektif Islam}

\author{
Rio Febriannur Rachman \\ Institut Agama Islam Syarifuddin Lumajang \\ riofrachman21@gmail.com
}

\begin{abstract}
This article explores one of the policies of the City Government of Surabaya, to overcome the problem of poverty, through expanding employment. By launching KORIDOR Co-Working Scape, those are facilities for the community, to develop capabilities in the digital-based creative industry. This policy is expected to produce entrepreneurs who will recruit workers. The fasilities are representative places, computers, internet, and digital business assistance in the form of intensive training from experts. Observations made using qualitative methods with a case study approach. The theory used in seeing this phenomenon is public policy. Also, by looking, whether this policy is in line with the maqâsid al-syari'ah, which is the concept of protecting the religion, life, mind, descent, and property of each member of the community. Economic development to realize al-'adalah al-iqtishodiyah (economic justice) through the development of digital media-based creative industries, can provide protection to five aspects of maqâsid al-syarî'ah. The majority of Muslim intellectuals argue that economic development efforts include those from Jihad fi Sabilillah (holy struggle in the way of God). While the use of digital media, as long as it does not violate the law of the principle of transactions in Islam, is permitted. It proves, the Islamic openness to the development of science and technology.
\end{abstract}

[Artikel ini mengupas salah satu kebijakan Pemerintah Kota Surabaya untuk mengatasi persoalan kemiskinan, melalui perluasan lapangan kerja. Caranya, dengan meluncurkan KORIDOR, Co-Working Scape, yang merupakan fasilitas dan sarana bagi masyarakat, untuk mengembangkan kemampuan di bidang industri kreatif berbasis digital. Kebijakan ini diharapkan dapat mencetak para pengusaha yang bakal merekrut tenaga kerja. Program ini berwujud penyediaan fasilitas dan sarana berupa tempat yang representatif, komputer, internet, serta pendampingan bisnis digital berupa pelatihan-pelatihan intensif dari para ahli. Pengamatan yang dilakukan memakai metode kualitatif dengan pendekatan studi kasus. Teori yang dipakai dalam melihat fenomena ini adalah kebijakan publik. Juga, dengan melihat keselarasan kebijakan ini dengan maqâsid al-syarîah, yang merupakan konsep perlindungan agama, jiwa, akal, keturunan, dan harta tiap anggota masyarakat. Pembangunan ekonomi untuk mewujudkan al-'adalah aliqtishodiyah melalui pengembangan industry kreatif berbasis media digital dapat memberikan perlindungan pada lima aspek maqâsid al-syarî'ah. Mayoritas intelektual muslim berpendapat bila upaya pembangunan ekonomi termasuk dari Jihad fi Sabilillah. Sementara penggunaan media digital, selama tidak melanggar hukum prinsip transaksi dalam Islam, diperbolehkan dan ini merupakan bentuk keterbukaan Islam terhadap perkembangan ilmu pengetahuan dan teknologi.

Keywords: Public Policy, Co-Working Space, Surabaya, maqâsid al-syarî’ah 
Rio Febriannur Rachman

\section{A. PENDAHULUAN}

Kemiskinan merupakan problem yang umumnya menerpa kota-kota besar di dunia. Termasuk, di Surabaya, sebagai salah satu kota besar di Indonesia, negara berpenduduk terbanyak kelima. Tak bisa dimungkiri, Surabaya masih menghadapi masalah laten kemiskinan ${ }^{1}$. Untuk mengatasi masalah tersebut, Pemerintah Kota Surabaya mencetuskan sejumlah kebijakan ${ }^{2}$. Pemerintah Kota Surabaya memang memiliki tanggungjawab terhadap pemberantasan kemiskinan, terlebih, Perserikatan Bangsa-Bangsa melalui jargon Tujuan Pembangunan Berkelanjutannya (Suistanable Development Goals) menggariskan, semua kebijakan pemerintah mesti linier dengan tujuh belas poin pembangunan berkelanjutan, yang salah satunya adalah No Poverty atau meniadakan kemiskinan ${ }^{3}$. Berdasarkan sumber penyebabnya, ada beberapa faktor yang mengakibatkan kemiskinan, salah satunya, tidak adanya lapangan pekerjaan yang menjanjikan ${ }^{4}$.

Pada bagian lain, perkembangan teknologi komunikasi dan informasi berjalan pesat di kota-kota besar, termasuk di Surabaya. Masyarakat di kota ini, umumnya telah akrab dengan dunia digital, internet, dan media sosial. Fenomena ini merupakan tantangan sekaligus peluang. Secara khusus, Pemerintah Kota Surabaya berupaya merumuskan kebijakan agar pemanfaatan teknologi masyarakat bisa dilakukan secara produktif. Apalagi, Pemerintah Kota Surabaya sudah dikenal sebagai kota yang konsisten untuk melakukan optimalisasi teknologi demi reformasi birokrasi ${ }^{5}$.

Bagaimana memanfaatkan teknologi secara produktif? Masyarakat bisa

1 Hotman Siahaan, "Profil Kemiskinan di Surabaya: Sebuah Analisis Fenomenologis". Jurnal Kemiskinan (2011): 219-227.

${ }^{2}$ Rulam Ahmadi, "Pemberdayaan Masyarakat Miskin: Pendekatan Modal Manusia (Studi Layanan Publik tentang Pemberdayaan Masyarakat Miskin yang Diselenggarakan oleh BPM-KB dan Posko 100 di Kota Surabaya)". DIA: Jurnal IImiah Administrasi Publik 10, No. 2 (2012): 16-31.

3 “About the Sustainable Development Goals", 2015, diakses pada 11 September 2018 https://www.un.org/sustainabledevelopment/sustainable-development-goals/.

4 Husna Ni'matul Ulya, "Paradigma Kemiskinan Dalam Perspektif Islam Dan Konvensional”. El Barka: Journal Economic and Business 1, No. 1 (2018): 90-113

${ }^{5}$ Suhendra, AS. "Kesiapan Pemerintah Daerah dalam Mewujudkan Kota Cerdas di Bandung dan Surabaya". Matra Pembaruan: Jurnal Inovasi Kebijakan 1, No. 1 (2017): 19. https://doi.org/10.21787/mp.1.1.2017.1-9 
menggunakan teknologi komunikasi dan informasi sebagai modal menjalankan industri kreatif, mengoperasikan aplikasi-aplikasi teknologi untuk berwirausaha, maupun memromosikan produk-produk untuk dijual. Harapanya, masyarakat bisa menjadi pelaku usaha yang tidak hanya berstatus konsumer. Bertolak dari keinginan itu, Pemerintah Kota Surabaya mencetuskan program penyediaan sarana dan fasilitas Co-Working Space, pada 2017 silam $^{6}$. Co-Working Space bernama KORIDOR yang berlokasi di lantai 3, Gedung Siola, Jalan Tunjungan, dibuat untuk menciptakan ekosistem yang cocok untuk masyarakat, agar dapat menjadi kreator, inovator, dan entrepreneur atau pelaku usaha. Targetnya, mereka bisa bersaing di ranah global.

Di KORIDOR, terdapat fasilitas internet lengkap, komputer, suasana nyaman dengan penyejuk udara, serta atmosfer yang kondusif. Di sana, masyarakat bisa belajar tentang industri kreatif dan media digital. Mereka yang bertemu, bisa saling berdiskusi serta berkarya secara kolaboratif. Beberapa ruang juga sudah disiapkan untuk kegiatan-kegiatan rutin seperti pelatihan tentang teknologi digital, markas komunitas muda, juga pameran karya seni rupa. Pada kegiatan, pelatihan, workshop serta forum diskusi tersebut, banyak narasumber berlevel regional, nasional, dan internasional, termasuk dari pihak facebook maupun google. Terdapat pula tokoh nasional seperti Chairul Tanjung, Dennis Adiswara, Vidi Aldiano, serta KORIDOR juga pernah mendapat kunjungan dari kedutaan Inggris dan Kroasia.

Melalui KORIDOR, Pemerintah Kota Surabaya menciptakan wadah inkubasi untuk pengembangan potensi masyarakat dalam industri kreatif dan media digital. Muaranya, terlahir lapangan pekerjaan baru dari tiap pelaku usaha. Hingga pertengahan 2019, sudah ada 77 bisnis rintisan (start up), yang memiliki basecamp di KORIDOR. Sementara itu, pengunjung yang datang ke KORIDOR tiap hari, ratarata konsisten di kisaran 253 orang. Artinya, ada kebermanfaatan yang berkelanjutan di sana ${ }^{7}$.

Artikel ini mengupas kebijakan Pemerintah Kota Surabaya dalam bidang pengembangan industri kreatif berbasis media digital melalui pengadaan CoWorking Space, berdasarkan teori maupun konsep kebijakan publik. Kebijakan

6 Bagian Organisasi Pemerintah Kota Surabaya, Inovasi Pelayanan Publik. (Surabaya: Tidak diterbitkan, 2019)

7 Wawancara dengan Kepala Sub Bagian Layanan Informasi, Humas Pemkot Surabaya, Yanuar Hermawan, 7 Juli 2019 
Rio Febriannur Rachman

publik didefinisikan sebagai tindakan yang memunyai tujuan tertentu, dan dilaksanakan oleh pemerintah secara resmi ${ }^{8}$. Kebijakan publik dapat dianalisis secara evaluatif, dengan cara melihat kondisi masyarakat sebelum dan sesudah dijalankannya kebijakan tersebut ${ }^{9}$. Dilihat pula keselarasannya dengan maqâsid alsyarî’ah, yang oleh sejumlah ulama dianggap sebagai nilai-nilai dan sasaran hukum agama ${ }^{10}$. Nilai dan sasaran tersebut secara umum berorientasi merealisasikan kemaslahatan umat ${ }^{11}$.

Metode yang dipakai kualitatif, untuk menghasilkan deskripsi menyeluruh dari kondisi lapangan, melalui pembahasan terhadap dokumen maupun kutipan wawancara yang relevan. Penelitian kualitatif menempatkan peneliti atau penulis sebagai instrument utama yang berkonsentrasi pada elemen empiris guna menerangkan keadaan faktual ${ }^{12}$.

Pendekatan yang digunakan adalah studi kasus. Studi kasus merupakan bentuk penelitian yang mengamati fenomena aktual dengan konteks terukur serta unik $^{13}$. Kebijakan pengadaan Co-Working Space oleh pemerintah daerah umumnya dilakukan dengan menggandeng pihak swasta atau eksternal. Di Surabaya, uniknya, Co-Working Space ini dikelola langsung oleh Pemerintah Kota Surabaya melalui Bagian Hubungan Masyarakat, serta buka selama 24 jam non-stop. Keunikan lainnya, pada 2019 ini, kebijakan yang kemudian dinamakan dengan Cak eMus ini meraih penghargaan Top 99 Inovasi Pelayanan Publik, dari Kementerian Dalam Negeri. Teknik pengumpulan data yang dilakukan adalah, pertama, studi dokumen/literatur yang berkenaan dengan kebijakan ini. Kedua, wawancara dengan narasumber yang berkompeten, ketiga, observasi.

\section{B. KEBIJAKAN APLIKATIF MEWUJUDKAN AL-'ADALAH AL- IQTISHODIYAH}

Pemerintah Daerah, termasuk Pemerintah Kota Surabaya, memiliki

\footnotetext{
${ }^{8}$ James E. Anderson, Public Policy Making (New York: Holt, Rinehart and Winston, 1984)

${ }^{9}$ William N. Dunn, Pengantar Analisis Kebijakan Publik (Yogyakarta: Gajah Mada University Press, 2000)

10 Wahbah al-Zuhaili, Ushûl al-Fiqh al-Islâmi (Damaskus: Dâr al-Fikri, 1986) 2003)

${ }^{11}$ Al-Syâthibî, Al-Muawâfaqat Fi Ushul al-Syari'ah (Beirut: Dâr al-Kutub al-IImiyah,

12 YvonnaS. Lincoln \& Egon G. Guba, Naturalistic Inquiry (California:Sage. 1985)

13 Robert K. Yin, Case Study Research: Design and Methods (London: Sage Publication, 2003)
} 
kewenangan untuk membuat dan melaksanakan kebijakan publik. Kebijakan publik merupakan apa yang dilakukan pemerintah yang berhubungan dengan isu kemasyarakatan, demi kesejahteraan umum ${ }^{14}$. Pemerintah berhak membuat hukum atau regulasi, yang mengerahkan struktur-struktur di dalamnya, demi kepentingan masyarakat ${ }^{15}$. Kebijakan publik bertujuan untuk memecahkan suatu masalah, misalnya masalah kemiskinan, dengan cara membuka lapangan pekerjaan. Bertolak dari konsep tersebut, bisa dipastikan kalau penyediaan KORIDOR Co-Working Space merupakan kebijakan publik yang ditelurkan oleh Pemerintah Kota Surabaya.

Sejumlah pemikir menyebutkan, kebijakan publik dikonstruksikan oleh tiga level hierarkis: policy level, organizational level, operational level ${ }^{16}$. Policy level biasanya dijalankan yudikatif dan legislative. Organizational level dijalankan oleh eksekutif. Operational level dilaksanakan oleh perangkat dari pihak eksekutif. Sebagai contoh, di tingkat Pemerintah Pusat, perangkat yang dimaksud adalah kementerian, di tingkat Pemerintah Provinsi, perangkat yang dimaksud adalah Biro, Dinas, dan lain-lain, sedangkan di tingkat Pemerintah Kabupaten/Kota, ada dinas, bagian, badan, dan sebagainya.

Semua kebijakan publik, dilindungi dan didasari institutional arrangement atau peraturan perundang-undangan yang sah. Wujudnya berbeda-beda di setiap tingkat, antara lain, Undang-Undang, Peraturan Presiden, Peraturan Pemerintah, Keputusan Presiden, Peraturan Menteri, Peraturan Daerah, Peraturan Gubernur, Peraturan Walikota, Peraturan Bupati, dan lain sejenisnya. Seluruh regulasi, mengacu pada peraturan-peraturan lain sebelumnya, sehingga ada konsistensi dan keberlanjutan dalam setiap elemennya.

Penyediaan KORIDOR Co-Working Space merupakan salah satu kebijakan publik di Surabaya. Policy level dari kebijakan ini diperankan oleh legislatif atau Dewan Perwakilan Rakyat Daerah (DPRD) Surabaya. DPRD mengesahkan anggaran eksekutif dalam kebijakan ini. Organizational level dipegang Pemerintah Kota Surabaya. Ada pun operational level dilaksanakan oleh Bagian Humas sebagai perangkat yang menjadi leading sector kebijakan ini. Institutional arrangement dari kebijakan ini setidaknya didasarkan pada adanya Peraturan Daerah tentang APBD

\footnotetext{
14 Thomas R. Dye, Understanding Public Policy (New Jersey: Prentice Hall, 1972)

15 James E. Anderson, Public Policy Making (New York: Holt, Rinehart and Winston, 1984)

${ }^{16}$ Tachjan, Implementasi Kebijakan Publik (Bandung: AIPI, 2006)
} 
Rio Febriannur Rachman

tahunan, yang eksisting sejak 2017 hingga tahun ini, yang di dalamnya ada aturan untuk penggunaan anggaran buat kebijakan ini.

Bagaimana implementasi kebijakan ini dapat dilihat dari aspek kebermanfaatan, dengan meninjau apa yang ada sebelum dan sesudah kebijakan ini berjalan. Secara prinsip, ada sejumlah manfaat yang dirasakan masyarakat. Antara lain, warga di Surabaya memiliki alternatif tempat untuk belajar yang representatif, karena terdapat fasilitas internet gratis di dalamnya ${ }^{17}$. Mereka juga punya wadah berkumpul yang nyaman, yang dapat digunakan untuk menggarap tugas sekolah, kuliah, maupun pekerjaan ${ }^{18}$.

Kebermanfaatan kebijakan ini juga dapat ditelaah dari lini sosial dan ekonomi. Bila diperhatikan, semua program atau kegiatan yang ada di KORIDOR Co-Working Space sesuai dengan cita-cita Pemerintah Kota Surabaya yang ingin mengangkat harkat dan martabat masyarakat di bidang ekonomi. Sudah barang tentu, adanya kesetaraan sosial di masyarakat merupakan keinginan yang ditargetkan pula. Wawasan di bidang industri kreatif berbasis media digital merupakan poin penting di era kekinian. Khususnya, di era masyarakat informasi, di mana orang-orang sangat dekat dengan segala macam informasi yang terkoneksi dengan internet ${ }^{19}$.

Yang tak kalah menarik, kegiatan di KORIDOR Co-Working Space selalu melibatkan banyak pihak. Selain para Aparatur Sipil Negera (ASN) di setiap Perangkat Daerah (PD), ada pula pihak-pihak dari eksternal Pemerintah Kota Surabaya. Mereka antara lain mengambil posisi sebagai relawan yang menjadi petugas di sana sehari-hari, narasumber pelatihan, dan peran-peran sentral lainnya. Terdapat pula beberapa komunitas professional yang berkolaborasi dengan memberi bantuan atau berbagi pada masyarakat yang menggunakan fasilitas di sana, antara lain, komunitas Start Surabaya Gapura Digital, Gerakan Nasional 1000 Start Up Digital, Android Kejar Indonesia, Tata Rupa, dan Kreavi. Pemerintah Kota Surabaya tak segan berkolaborasi dengan pihak swasta untuk menjadi sponsor atau

\footnotetext{
${ }^{17}$ Wawancara di KORIDOR Co-Working Space, dengan pengunjung yang seorang mahasiswi di kampus yang ada di Surabaya, tapi ber-KTP Sidoarjo, pada 4 April 2019

${ }^{18}$ Wawancara di KORIDOR Co-Working Space, dengan pengunjung yang seorang siswi dari Surabaya, pada 4 April 2019

${ }^{19}$ Fredian Tonny Nasdian, Pengembangan Masyarakat. (Jakarta: Yayasan Pustaka Obor Indonesia, 2014)
} 
pendukung acara ${ }^{20}$.

Kebijakan ini menumbuhkan mekanisme kemitraan antara semua eksponen masyarakat. Terlebih, para aktifis yang telah sukses memiliki industri kreatif, baik di bidang start up, desainer grafis, manajemen website maupun media sosial, diarahkan pula untuk berkolaborasi dengan Usaha Mikro Kecil dan Menengah (UMKM) yang tergabung di program Pahlawan Ekonomi dan Pejuang Muda Surabaya ${ }^{21}$. Artinya, ada korelasi antara program satu dengan program lain di lingkup Pemerintah Kota Surabaya.

UMKM yang umumnya berasal dari keluarga dengan ekonomi lemah, ikut terbantu karena produknya menjadi lebih bernilai jual. Jaringan UMKM bertambah luas, berkat pendampingan yang optimal. Kolaborasi UMKM dengan para aktifis di KORIDOR Co-Working Space membuat pelaku usaha menjadi lebih produktif $^{22}$. Kemasan produk mereka juga lebih mantap karena bantuan para desainer grafis yang bereputasi ${ }^{23}$.

Pada bagian lain, terjalin kebersamaan antar anggota masyarakat atau umat di suatu wilayah, demi pertumbuhan dan keadilan pemerataan ekonomi. Dalam konteks kebersamaan ini, Islam mengajarkan umat untuk berjuang secara berjamaah. Ada keselarasan antara kebijakan penyediaan KORIDOR Co-Working Space ini dengan perintah Islam, untuk menegakkan kebaikan dan kebenaran dalam barisan yang rapat selayaknya suatu bangunan yang tersusun kokoh ${ }^{24}$. Implementasi kebersamaan dan persatuan umat melalui kemitraan ini, juga senafas dengan sebuah riwayat yang mewajibkan kaum muslimin untuk bersatu

20 "Inovasi Co-Working Space", 2018, diakses pada 16 Mei 2019 https://organisasi.surabaya.go.id/home/file/pelayanan\%20publik/masuk\%20web/proposal \%20\%20koridor.pdf

21 Rio Febriannur Rachman, "Optimalisasi Media Digital Berbasis Kemaslahatan Umat dalam Program Pahlawan Ekonomi Surabaya". Iqtishoduna: Jurnal Ekonomi Islam 8, No. 2 (Oktober 2019): 273-292

22 Abdul Hakim, "Pahlawan Ekonomi Efektif Kembangkan Industri Kreatif di Surabaya", Antara News, $20 \quad$ Maret 2019, https://m.antaranews.com/amp/berita/812795/pahlawan-ekonomi-efektif-kembangkanindustri-kreatif-di-surabaya

23 "Walikota Risma Kembali Melaunching Tata Rupa Prime yang Bantu Desain Produk UKM Surabaya", 2018, diakses pada 28 Juli 2019, https://humas.surabaya.go.id/2018/08/13/wali-kota-risma-kembali-melaunching-tata-rupaprime-yang-bantu-desain-produk-ukm-surabaya/

${ }^{24}$ Al-Quran Surah Ash-Shof (61) ayat 4 
Rio Febriannur Rachman

di Al-Jamaah atau kelompok, sekaligus waspada pada bibit-bibit perpecahan yang mungkin timbul dari hasad maupun kedengkian ${ }^{25}$.

Di antara tujuh belas poin dari Tujuan Pembangunan Berkelanjutan yang dicetuskan Perserikatan Bangsa-Bangsa ${ }^{26}$, terdapat poin Suistainables Cities and Comunities. Kebijakan penyediaan KORIDOR Co-Working Space selaras dengan poin ini, karena memererat hubungan komunal di kota Surabaya. Kebijakan ini juga selaras dengan poin Life in Land, karena basis dari industri kreatif di sini berfokus pada ranah digital. Artinya, ada semangat paperless, yang sesuai dengan upaya mengurangi penebangan pohon sebagai salah satu kehidupan yang ada di muka bumi. Yang secara tidak langsung pula, senada dengan poin Climate Action atau upaya melestarikan lingkungan sebagai sikap pada isu perubahan iklim.

Ada sejumlah tujuan dari penerapan hukum Islam di bidang ekonomi, salah satunya, terjadinya pemerataan atau keadilan ekonomi atau Al-'adalah Aliqtisadiyah. Sebagian ulama mengkiaskan, keadilan ekonomi tersebut berkaitan dengan distribusi pendapatan dan atau kekayaan ${ }^{27}$. Islam mengajarkan pada para penganutnya, untuk mengupayakan kebersamaan dalam menikmati kekayaan yang ada di muka bumi, tidak serakah, sehingga harta kekayaan tidak Cuma beredar dalam satu kelompok konglomerasi ${ }^{28}$. Patut diketahui, bahwa harta, uang maupun produk-produk konsumsi, harus beredar di masyarakat tanpa adanya monopoli, karena ia memiliki fungsi sosial ${ }^{29}$.

Kebijakan pengembangan industri kreatif berbasis media digital, melalui penyediaan KORIDOR, yang digelorakan oleh Pemerintah Kota Surabaya terbukti memberikan dampak bagi masyarakat. Implementasi kebijakan tersebut dapat diukur dan dilihat secara transparan. Pengukuran bisa dilaksanakan secara komprehensif sejak tahap perumusan, implementasi, dan evaluasi, dengan melihat kondisi sebelum dan sesudah kebijakan berjalan, dengan melihat tujuantujuan yang telah dicapai ${ }^{30}$. Apa yang dilakukan Pemerintah Kota Surabaya ini,

25 HR Tirmidzi

26 "About the Sustainable Development Goals", 2015, diakses pada 11 September 2018, https://www.un.org/sustainabledevelopment/sustainable-development-goals/. Diakses pada 11

27 Al-Quran Surah Al Hasyr (59) ayat 7

28 Ruslan Abdul Ghofur Noor, "Kebijakan Distribusi Ekonomi Islam dalam Membangun Keadilan Ekonomi Indonesia”, Islamica, 6, No. 2 (Maret 2012): 316-328

${ }^{29}$ M. Quraish Shihab, Tafsir al-Mishbah, Vol. 14 (Jakarta: Lentera Hati, 2002)

${ }^{30}$ Budi Winarno, Kebijakan Publik: Teori dan Proses (Yogyakarta: Med Press, 2007) 
merupakan wujud tanggungjawab pemerintah, yang sudah seharusnya ikut berperan sentral dalam mengatur perekonomian masyarakat di semua lapisan ${ }^{31}$.

Kebijakan ekonomi yang berorientasi pada kesejahteraan masyarakat, memang merupakan tanggungjawab pemerintah. Keadilan ekonomi harus dikelola dengan baik oleh pemerintah di setiap level, baik negara maupun daerah ${ }^{32}$. Di sisi lain, bila ditelaah dengan seksama, pengembangan industri kreatif berbasis media digital melalui pengadaan Co-Working Space, memiliki upaya menguatkan ekonomi kerakyatan. Di dalam ekonomi yang kuat, keselamatan jiwa, harta, keturunan dan akal, bahkan iman seseorang bisa lebih terjaga, yang lima hal tadi merupakan elemen prinsip dalam prinsip maqâsid al-syarî’ah.

\section{TEKNOLOGI KOMUNIKASI DAN INFORMASI SEBAGAI SARANA MUAMALAH}

Di era masyarakat digital seperti sekarang ini, pemanfaatan teknologi komunikasi dan informasi bagi semua eksponen masyarakat, termasuk institusi pemerintah, sudah tidak terelakkan ${ }^{33}$. Oleh sebab itu, apa yang dilakukan Pemerintah Kota Surabaya dengan penyediaan KORIDOR Co-Working Space, sebagai penopang industri kreatif berbasis digital di masyarakat, merupakan langkah kongkret menjawab tantangan zaman. Sudah sepantasnya, pemerintah di setiap level, pada masing-masing institusi, sanggup mengelola kemajuan teknologi sehingga semua potensi bisa dimaksimalkan ${ }^{34}$.

Pemerintah mesti lihai menyandingkan kemajuan teknologi komunikasi dan informasi dengan misi kepentingan kebijakan ${ }^{35}$. Termasuk di dalamnya, pada kebijakan yang berkenaan dengan penyebaran informasi, sosialisasi, promosi, dan

${ }^{31}$ M. Arif Hakim, "Peran Pemerintah Dalam Mengawasi Mekanisme Pasar Dalam Perspektif Islam". Iqtishadia, 8, No. 1, (Maret 2015): 19-40

32 Indra Hidayatullah. "Peran Pemerintah dalam Stabilitas Ekonomi Pasar". Iqtishoduna: Jurnal Ekonomi Islam, 8, No. 1 (April 2019): 183-208

33 Rio Febriannur Rachman. "Menelaah Riuh Budaya Masyarakat di Dunia Maya." Jurnal Studi Komunikasi 1. No. 2 (2017): 206-222.

${ }^{34}$ Sad Dian Utomo, "Partisipasi Masyarakat dalam Pembuatan Kebijakan" dalam Indra J. Piliang, Dendi Ramdani, dan Agung Pribadi, Otonomi Daerah: Evaluasi dan Proyeksi, (Jakarta: Penerbit Divisi Kajian Demokrasi Lokal Yayasan Harkat Bangsa, 2003)

${ }^{35}$ Ayuning Budiati, et al. "IT governance sektor publik di Indonesia: Konsep dan kebijakan", Prosiding Konferensi Nasional Teknologi Informasi \& Komunikasi untuk Indonesia (2006): 57-61 
Rio Febriannur Rachman

apa saja yang secara nyata berkaitan dengan masyarakat luas ${ }^{36}$. Terlebih, berdasarkan data Asosiasi Pengguna Jasa Internet, di tahun $2016^{37}$, terdapat 132,7 juta orang atau setara dengan 60 persen penduduk Indonesia yang telah terakses oleh internet. Sedangkan bila melihat dari jumlah penggunaan gawai, angka unit yang dimiliki, berada di atas jumlah manusia yang memiliki gawai, hingga 130 persen. Dengan kata lain, seseorang bisa jadi memiliki dua atau lebih gawai.

Masyarakat makin dekat dengan dunia digital. Sehingga apa yang dilakukan Pemerintah Kota Surabaya dengan memberi fasilitas dan sarana pemanfaatan internet sudah selaras dengan era kekinian. Aktivitas manusia belakangan ini sudah dipengaruhi arus informasi yang terhubungan secara digital melalui internet. Sejalan dengan itu, masyarakat makin bergantung pada informasi yang diperoleh secara lebih lekas melalui gawai ${ }^{38}$.

Islam memiliki sifat inklusif terhadap segala jenis perubahan sosial ${ }^{39}$. Maka itu, perkembangan ilmu pengetahuan dan teknologi, selalu bisa diterima dan kompatibel dengan agama ini ${ }^{40}$. Pada bidang bermuamalah, termasuk bertransaksi atau berbisnis, Islam juga tidak anti pada penggunaan teknologi. Oleh sebab itu, industri kreatif berbasis media digital juga tidak masuk dalam kategori terlarang. Bila ditarik lebih jauh, jual beli online juga mendapat ruang. Meski memang, jual beli konvensional maupun yang berbasis kemajuan teknologi komunikasi dan informasi atau online ada yang haram, serta ada yang hala ${ }^{41}$.

Sebagian ulama berpendapat, asalkan memenuhi rukun akad syariah, jual beli online diperbolehkan ${ }^{42}$. Rukun tersebut di antaranya,

${ }^{36}$ Rachmat Kriyantono. "Konstruksi humas dalam tata kelola komunikasi lembaga pendidikan tinggi di era keterbukaan informasi publik". Pekommas (2015): 18.2

37 "Survey Internet APJII 2016", 2016, diakses pada 23 Januari 2019, https://apjii.or.id/content/read/39/264/Survei-Internet-APJII-2016

38 Rahma Sugihartati, Perkembangan Masyarakat Informasi \& Teori Sosial Kontemporer. (Jakarta: Kencana, 2014)

39 Fathurrahman Azhari, "Dinamika Perubahan Sosial Dan Hukum Islam". At-Tahrir: Jurnal Pemikiran Islam 16, No. 1 (2016): 197-221

40 Jamal Fakhri, "Sains Dan Teknologi Dalam Al-Qur'an". TA'DIB 15. No. 1. (Juni 2010): 121-142

${ }^{41}$ Tira Nur Fitria, "Bisnis Jual Beli Online (Online Shop) Dalam Hukum Islam Dan Hukum Negara". Jurnal IImiah Ekonomi Islam, 3. No. 1 (Maret 2017): 52-62

42 M. Nur Rianto Al Arif, "Penjualan on-line berbasis media sosial dalam perspektif ekonomi Islam". ljtihad, Jurnal Wacana Hukum Islam dan Kemanusiaan, 13, No. 1, (Juni 2013): 33-48 
terdapat penjual dan pembeli, sighah atau ijab qobul di mana kedua belah pihak menyetujui syarat dan kondisi dalam transaksi, kejelasan objek pada transaksi, dan tujuan akad harus linier dengan syariat, dan tidak untuk merugikan agama atau humanisme ${ }^{43}$. Sementara itu, azas yang menjadi syarat sah jual beli online adakah kehalalan dan kejelasan produk ${ }^{44}$, mutu dan harga sesuai, serta adanya kejujuran, kesepakatan, dan saling kerelaan ${ }^{45}$.

Penjelasan tentang jual beli online ini penting disampaikan, berkenaan dengan kegiatan yang ada di KORIDOR Co-Working Space, sebab dalam kegiatan di sana ada aktifitas penguatan e-commerce atau jual beli online. Terlebih, di era digital seperti keberadaan transaksi online tidak bisa terbantahkan ${ }^{46}$. Salah satu topik pelatihan yang digandrungi masyarakat juga berhubungan dengan e-commerce. Seperti sempat disampaikan di bagian terdahulu, para aktifis di KORIDOR Co-Working Space juga memberi pendampingan pada UMKM di Surabaya, di mana mereka diminta untuk memanfaatkan media digital dan media sosial demi pemasaran ${ }^{47}$. Di KORIDOR Co-Working Space sendiri, terdapat sejumlah narasumber dari facebook dan Google ${ }^{48}$ yang telah memiliki agenda pelatihan rutin. Tentu saja, tema yang disampaikan seputar penumbuhan industry kreatif dan optimalisasi media digital.

Kebijakan KORIDOR Co-Working Space ini tidak sukar direplikasi atau kompatibel untuk dilaksanakan di daerah lain ${ }^{49}$. Yang terpenting, terdapat

${ }^{43}$ Muhammad bin Idris al-Shafi'i. al-Umm. (Damasukus: Dar al-Fikr, 1990)

${ }^{44}$ Abi Bakr bin Mas'ud al-Kasani. Badai' al-Sanai' fi Tartib al-Sharai'. (Beirut: Dar alKutub al-'Ilmiyyah, 2003)

${ }^{45}$ Nasrul Hisyam Nor Muhamad, "Aplikasi Sains Dan Teknologi Dalam Transaksi Muamalah Islam". Jurnal Teknologi: Universiti Teknologi Malaysia 49, No. 1 (2008): 81-91

${ }^{46}$ Annisa Dwi Kurniawati, "Transaksi E-Commerce Dalam Perspektif Islam", elBarka: Journal Economic and Business, 2, No. 1, (Januari-Juni 2019): 90-113

47 Fitri Rachmawati. "Penerapan Digital Marketing sebagai Strategi Komunikasi Pemasaran Terpadu produk Usaha Kecil dan Menengah (UKM) Pahlawan Ekonomi Surabaya". Diss. UIN Sunan Ampel Surabaya, 2018.

${ }^{48}$ Gita Amanda, "Facebook Kunjungi Pelaku UMKM di Surabaya", Republika, 3 Juni 2019, $\quad$ https://www.republika.co.id/berita/ekonomi/korporasi/19/06/03/pshxaw423facebook-kunjungi-pelaku-umkm-di-surabaya 2018,

${ }^{49}$ Tomi Sudjatmiko, "Top Inovator Harus Tularkan Inovasinya", KR Jogja, 19 Juli https://krjogja.com/web/news/read/72249/Top_Inovator_Harus_Tularkan_Inovasinya 
Rio Febriannur Rachman

kekompakan antar eksponen masyarakat, dan adanya komitmen dari pemerintah setempat. Kebersamaan merupakan kunci utama. Kebanggaan dan rasa kekeluargaan yang merupakan kultur lokal Surabaya, menjadi kekuatan tersendiri dalam implementasi kebijakan di Surabaya ${ }^{50}$. Sejauh ini, telah banyak elemen pemerintah daerah maupun organisasi masyarakat dari pulau Jawa, Sulawesi, Kalimantan, Nusa Tenggara, Papua, dan lain sebagainya, yang melakukan studi banding ke tempat ini ${ }^{51}$.

Dalam Konferensi Tingkat Tinggi (KTT) Dunia untuk pembangunan sosial (World Summit on Social Development) di Kopenhagen, Denmark, pada 6-12 Maret 1995, disampaikan tiga dimensi yang perlu mendapat atensi semua pihak, khususnya pemerintah. Yakni, dimensi kemiskinan, dimensi ketenagakerjaan, dan dimensi integrasi sosial52. Semua kebijakan pemerintah, diharapkan punya korelasi terhadap tiga dimensi tadi.

Kebaradaan KORIDOR Co-Working Space bersentuhan dengan dimensi kemiskinan, karena program yang ada di dalamnya bertolak dari semangat membangkitkan ekonomi produktif guna memerangi kemiskinan. Bentuknya, dengan penyediaan lapangan kerja. Dalam aspek ini, pada konteks yang sama, dimensi ketenagakerjaan juga disentuh. Secara umum, pemerintah memang wajib menaruh perhatian pada penumbuhan ekonomi masyarakat yang berorientasi pada solusi atas kemiskinan dan ketenagakerjaan ${ }^{53}$. Apabila kemiskinan digerus, masyarakat sudah memiliki pekerjaan yang representative, kesenjangan sosial pun terkikis. Artinya, muncul integrasi sosial yang berlandaskan kesejahteraan ekonomi.

Islam mengatur keseimbangan antara kebutuhan individual dan sosial ${ }^{54}$. Maka itu, manusia tidak boleh egois dan memikirkan dirinya sendiri. Program yang ada di KORIDOR Co-Working Space bertumpu pada upaya kolaboratif. Di mana manusia sebagai makhluk sosial, bersama pihak-pihak atau orang lain, bergandeng

50 Soedarso, et al. "Dinamika Multikultural Masyarakat Kota Surabaya". Jurnal Sosial Humaniora, 6, No. 1 (2013): 62-75.

51 Wawancara dengan Kepala Sub Bagian Layanan Informasi, Humas Pemkot Surabaya, Yanuar Hermawan, 7 Juli 2019

52 Edi Suharto. Analisis Kebijakan Publik. (Bandung: CV Alfabeta, 2014)

53 Izzah Masruroh \& Muhammad Farid. "Pengaruh Pengelolaan Ekonomi Produktif dalam Mengentaskan Kemiskinan di Kota Lumajang”. Iqtishoduna: Jurnal Ekonomi Islam 8, No. 1, (April 2019): 209-229

54 Mursal \& Suhadi, "Implementasi Prinsip Islam dalam Aktivitas Ekonomi: Alternatif Mewujudkan Keseimbangan Hidup”, Jurnal Penelitian 9, No. 1, (Februari 2015): 67-92 
tangan meraih kesuksesan bersama. Manusia memang memiliki keinginan individu, tapi wajib tetap memerhatikan kondisi sekitar. Dengan demikian, keseimbangan terwujud dan keadilan dapat merata dirasakan umat ${ }^{55}$. Problem sosial, termasuk persoalan ekonomi, pasti lebih gampang dipecahkan bila dirumuskan bersama demi kemaslahatan umat.

Pengembangan industri kreatif berbasis media digital, baik dengan pemasaran karya-karya desain, website, e-commerce, dan penguatan UMKM, bertujuan untuk menumbuhkan iklim wirausaha. Hal itu selaras dengan anjuran Nabi Muhammad Sholallahu alaihi Wasalam, yang dalam salah satu riwayat menyampaikan, penghasilan terbaik adalah yang diperoleh dari upayanya sendiri, dan konsep wirausaha di KORIDOR Co-Working Soace ini juga berbasis pada kemandirian ${ }^{56}$. Dalam sejumlah riwayat disebutkan, para pedagang atau wirausahawan yang jujur akan mendapat kemuliaan dari Tuhan dan bersama orang-orang beruntung di akhirat kelak ${ }^{57}$. Yang terpenting, para penerima manfaat nantinya harus berorientasi pada penyediaan produk berupa barang dan jasa berkualitas ${ }^{58}$. Sebagaimana prinsip muamalah dalam Islam yang mengharuskan penyedia produk memberikan pelayanan terbaik. Mereka juga dilatih tentang pentingnya strategi dalam berwirausaha, ketekunan, inovasi, dan kreatifitas ${ }^{59}$.

\section{PENUTUP}

Pengembangan industri kreatif berbasis media digital di Surabaya, melalui pengadaan KORIDOR Co-Working Space dijalankan dengan mengabaikan azas kapitalisme. Sebab, Pemerintah Kota tidak berharap ada profit atau keuntungan dari material yang bersifat satu arah dari pemakaian sarana atau fasilitas tersebut. Tidak ada retribusi, pajak, atau pungutan lainnya. Pemerintah Kota Surabaya menyediakan sarana dan fasilitas, agar masyarakat bangkit dan berkreasi di sana,

${ }^{55}$ Heri Junaidi \& Cholidi Zainuddin, "Prinsip-Prinsip Ekonomi Islam: Sebuah Kajian Awal”, Jurnal Muamalah 3 No. 1 (Juni 2017): 1-14

${ }^{56} \mathrm{HR}$. Ibnu Majah di dalam As-Sunan

${ }^{57}$ HR Tirmidzi nomor 1209

58 Sri Hartini, "Peran Inovasi: Pengembangan Kualitas Produk Dan Kinerja Bisnis". Jurnal Manajemen dan Kewirausahaan 14, No. 1 (2012): 83-90.

59 P. Surjani, "Manajemen Strategi Dalam Menghadapi Era Globalisasi". Unitas 11. No. 1 (2002): 20-36. 
Rio Febriannur Rachman

menjalankan industri kreatif, dan berkolaborasi. Muaranya, tercapai kesejahteraan bersama sehingga senada dengan prinsip ekonomi Islam ${ }^{60}$.

Melalui kebijakan ini, diharapkan muncul simbiosis mutualisme, yang menguntung Pemerintah Kota Surabaya dalam wujud pelayanan aplikatif, dan yang menguntungkan masyarakat secara individu maupun komunal. Pada satu titik, muncul kondisi di mana masyarakat menjadi kreatif dan inovatif, serta sanggup memanfaatkan media digital secara maksimal. Mekanisme ekonomi yang saling menguntungkan tanpa eksploitasi pihak-pihak tertentu ini, selaras dengan kaidah Islam yang humanis dan universal ${ }^{61}$.

Dalam perkembangan pemikiran Islam, sejumlah ulama kontemporer menyebutkan, maqâsid al-syarî'ah atau tujuan adanya hukum syariah, merupakan konsep yang berkonsentrasi pada terciptanya perlindungan bagi agama, jiwa, akal, keturunan, dan harta manusia ${ }^{62}$. Kebijakan yang berbasis pembangunan ekonomi, termasuk di dalamnya yang berfokus pada industry kreatif berbasis media digital, berpotensi mewujudkan perlindungan pada lima poin yang dimaksud $^{63}$. Lebih lanjut, bila mengacu pada pendapat sebagian pakar yang menyebutkan bila pembangunan ekonomi termasuk dari Jihad fi Sabilillah ${ }^{64}$, apa yang dilakukan di Surabaya ini pun bisa masuk kategori perjuangan di bawah panji agama.

Sebagai bentuk kebijakan publik, adanya KORIDOR Co-Working Space dapat dilihat secara objektif di aspek kebermanfaatannya ${ }^{65}$. Selain data yang menunjukkan adanya konsistensi pengunjung, dan jumlah komunitas yang terus berproduksi di sana, serta kolaborasi dengan UMKM di kota ini, banyaknya pengunjung saat adanya pelatihan-pelatihan industri kreatif berbasis media digital juga dapat dijadikan variabel ukuran. Warga yang memiliki senses of belonging

${ }^{60}$ Zainil Ghulam. "Membincang Ekonomi Islam dan Kapitalisme". Iqtishoduna: Jurnal Ekonomi Islam, 4, No. 2, (Oktober 2015): 1-12

${ }^{61}$ Muhammad Hanif al Hakim, "The Behaviour Of Economic Agent In Islam". ElBarka: Journal Economic and Business. 2, No. 1 (Januari - Juni 2019): 1-24

62 Ali Mutakin, "Teori Maqâshid Al Syarî'ah Dan Hubungannya Dengan Metode Istinbath Hukum". Kanun Jurnal IImu Hukum, 19. No. 3, (Agustus 2017): 547-570

${ }^{63}$ Muhammad Abdul Mun'im Affar, al-Takhtith wa al-Tanmiyah fi al-Islam, (Jeddah: Dar al-bayan al-Arabi, 1985) 151

${ }^{64}$ Asmuni, "Konsep Pembangunan Ekonomi Islam". Al Mawarid, edisi X (2003): 128-

${ }^{65}$ William N. Dunn. Pengantar Analisis Kebijakan Publik. (Yogyakarta: Gajah Mada University Press, 2000) 
terhadap fasilitas di sana, sehingga ikut menjaga dan merawat sarana yang ada, juga merupakan salah satu wujud keberhasilan program.

Kebijakan ini menjadi terjamin keberlanjutannya karena ada atensi khusus dari Wali Kota Surabaya, sebagai pemimpin tertinggi di Pemerintah Kota Surabaya. Juga, kehadiran pihak DPRD untuk memberi pendapat, masukan, atau kritikan. Media Massa atau pers, juga dipersilakan menjadi unsur kontrol sosial. Semua program di KORIDOR Co-Working Space dijalankan secara transparan dan siap menghadapi masukan dari masyarakat yang bisa disalurkan melalui akun resmi media sosial Pemerintah Kota Surabaya.

\section{DAFTAR PUSTAKA}

Affar, Muhammad Abdul Mun'im. al-Takhtith wa al-Tanmiyah fi al-Islam,

Ahmadi, Rulam. "Pemberdayaan Masyarakat Miskin: Pendekatan Modal Manusia (Studi Layanan Publik tentang Pemberdayaan Masyarakat Miskin yang Diselenggarakan oleh BPM-KB dan Posko 100 di Kota Surabaya)". DIA: Jurnal IImiah Administrasi Publik 10, No. 2 (2012): 1631.

Al-Kasani, Abi Bakr bin Mas'ud. Badai' al-Sanai' fi Tartib al-Sharai'. (Beirut: Dar al-Kutub al-'Ilmiyyah, 2003)

Al-Syâthibî. Al-Muawâfaqat Fi Ushul al-Syari'ah. Beirut: Dâr al-Kutub al-Ilmiyah, 2003.

Al-Zuhaili, Wahbah. Ushûl al-Fiqh al-Islâmi. Damaskus: Dâr al-Fikri, 1986.

Amanda, Gita. "Facebook Kunjungi Pelaku UMKM di Surabaya", Republika, 3 Juni2019, https://www.republika.co.id/berita/ekonomi/korporasi/19/06/03/p shxaw423-facebook-kunjungi-pelaku-umkm-di-surabaya

Anderson, James E. Public Policy Making. New York: Holt, Rinehart and Winston, 1984. 
Rio Febriannur Rachman

Arif, M. Nur Rianto Al. "Penjualan on-line berbasis media sosial dalam perspektif ekonomi Islam". Ijtihad, Jurnal Wacana Hukum Islam dan Kemanusiaan, 13, No. 1, (Juni 2013): 33-48

Asmuni, “Konsep Pembangunan Ekonomi Islam". Al Mawarid, edisi X (2003): 128-151

Asosiasi Penyelenggara Jasa Internet Indonesia. "Survey Internet APJII 2016", 2016, diakses pada 23 Januari 2019, https://apjii.or.id/content/read/39/264/Survei-Internet-APJII-2016

Azhari, Fathurrahman. "Dinamika Perubahan Sosial Dan Hukum Islam". AtTahrir: Jurnal Pemikiran Islam 16, No. 1 (2016): 197-221

Bagian Humas Pemerintah Kota Surabaya. "Walikota Risma Kembali Melaunching Tata Rupa Prime yang Bantu Desain Produk UKM Surabaya", 2018, diakses pada 28 Juli 2019, https://humas.surabaya.go.id/2018/08/13/wali-kota-risma-kembalimelaunching-tata-rupa-prime-yang-bantu-desain-produk-ukm-surabaya/

Bagian Organisasi Pemerintah Kota Surabaya, Inovasi Pelayanan Publik. Surabaya: Tidak diterbitkan, 2019.

Bagian Organisasi Pemerintah Kota Surabaya. "Inovasi Co-Working Space", 2018, diakses pada $16 \quad$ Mei 2019, https://organisasi.surabaya.go.id/home/file/pelayanan\%20publik/masuk\% 20web/proposal\%20\%20koridor.pdf

Budiati, Ayuning et al. "IT governance sektor publik di Indonesia: Konsep dan kebijakan", Prosiding Konferensi Nasional Teknologi Informasi \& Komunikasi untuk Indonesia (2006): 57-61

Dunn, William N. Pengantar Analisis Kebijakan Publik. Yogyakarta: Gajah Mada University Press, 2000.

Dye, Thomas R. Understanding Public Policy. New Jersey: Prentice Hall, 1972. 
Fakhri, Jamal. “Sains Dan Teknologi Dalam AI-Qur'an”. TA’DIB 15. No. 1. (Juni 2010): 121-142

Fitria, Tira Nur. "Bisnis Jual Beli Online (Online Shop) Dalam Hukum Islam Dan Hukum Negara”. Jurnal IImiah Ekonomi Islam, 3. No. 1 (Maret 2017): 5262

Ghulam, Zainil. "Membincang Ekonomi Islam dan Kapitalisme". Iqtishoduna: Jurnal Ekonomi Islam, 4, No. 2, (Oktober 2015): 1-12

Hakim, Abdul. "Pahlawan Ekonomi Efektif Kembangkan Industri Kreatif di Surabaya", Antara News, 20 Maret 2019, https://m.antaranews.com/amp/berita/812795/pahlawan-ekonomi-efektifkembangkan-industri-kreatif-di-surabaya

Hakim, M. Arif Hakim. "Peran Pemerintah Dalam Mengawasi Mekanisme Pasar Dalam Perspektif Islam”. Iqtishadia, 8, No. 1, (Maret 2015): 19-40

Hakim, Muhammad Hanif al. "The Behaviour Of Economic Agent In Islam". ElBarka: Journal Economic and Business. 2, No. 1 (Januari - Juni 2019): 1 24

Hartini, Sri. "Peran Inovasi: Pengembangan Kualitas Produk Dan Kinerja Bisnis". Jurnal Manajemen dan Kewirausahaan 14, No. 1 (2012): 83-90.

Hidayatullah, Indra. "Peran Pemerintah dalam Stabilitas Ekonomi Pasar". Iqtishoduna: Jurnal Ekonomi Islam, 8, No. 1 (April 2019): 183-208

Jeddah: Dar al-bayan al-Arabi, 1985.

Junaidi, Heri \& Cholidi Zainuddin, "Prinsip-Prinsip Ekonomi Islam: Sebuah Kajian Awal", Jurnal Muamalah 3 No. 1 (Juni 2017): 1-14

Kriyantono, Rachmat. "Konstruksi humas dalam tata kelola komunikasi lembaga pendidikan tinggi di era keterbukaan informasi publik". Pekommas (2015): 18.2 
Rio Febriannur Rachman

Kurniawati, Annisa Dwi. "Transaksi E-Commerce Dalam Perspektif Islam”, elBarka: Journal Economic and Business, 2, No. 1, (Januari-Juni 2019): 90113

Lincoln, YvonnaS. \& Egon G.Guba. Naturalistic/nquiry. California:Sage, 1985.

Masruroh, Izzah \& Muhammad Farid. "Pengaruh Pengelolaan Ekonomi Produktif dalam Mengentaskan Kemiskinan di Kota Lumajang". Iqtishoduna: Jurnal Ekonomi Islam 8, No. 1, (April 2019): 209-229

Muhamad, Nasrul Hisyam Nor. "Aplikasi Sains Dan Teknologi Dalam Transaksi Muamalah Islam". Jurnal Teknologi: Universiti Teknologi Malaysia 49, No. 1 (2008): 81-91

Muhammad bin Idris al-Shafi'i. al-Umm. (Damasukus: Dar al-Fikr, 1990)

Mursal \& Suhadi, "Implementasi Prinsip Islam dalam Aktivitas Ekonomi: Alternatif Mewujudkan Keseimbangan Hidup”, Jurnal Penelitian 9, No. 1, (Februari 2015): 67-92

Mutakin, Ali. "Teori Maqâshid Al Syarî’ah Dan Hubungannya Dengan Metode Istinbath Hukum". Kanun Jurnal IImu Hukum, 19. No. 3, (Agustus 2017): $547-570$

Nasdian, Fredian Tonny. Pengembangan Masyarakat. Jakarta: Yayasan Pustaka Obor Indonesia, 2014.

Noor, Ruslan Abdul Ghofur. "Kebijakan Distribusi Ekonomi Islam dalam Membangun Keadilan Ekonomi Indonesia", Islamica 6, No. 2 (Maret 2012): 316-328

Perserikatan Bangsa-Bangsa. "About the Sustainable Development Goals", 2015, diakses pada $11 \quad$ September 2018 https://www.un.org/sustainabledevelopment/sustainable-developmentgoals/. 
Rachman, Rio Febriannur. "Menelaah Riuh Budaya Masyarakat di Dunia Maya." Jurnal Studi Komunikasi 1. No. 2 (2017): 206-222.

Rachman, Rio Febriannur. "Optimalisasi Media Digital Berbasis Kemaslahatan Umat dalam Program Pahlawan Ekonomi Surabaya”. Iqtishoduna: Jurnal Ekonomi Islam 8, No. 2 (Oktober 2019): 273-292

Rachmawati, Fitri. "Penerapan Digital Marketing sebagai Strategi Komunikasi Pemasaran Terpadu produk Usaha Kecil dan Menengah (UKM) Pahlawan Ekonomi Surabaya”. Diss. UIN Sunan Ampel Surabaya, 2018.

Shihab, M. Quraish. Tafsir al-Mishbah, Vol. 14. Jakarta: Lentera Hati, 2002.

Siahaan, Hotman. "Profil Kemiskinan di Surabaya: Sebuah Analisis Fenomenologis". Jurnal Kemiskinan (2011): 219-227.

Soedarso, et al. "Dinamika Multikultural Masyarakat Kota Surabaya". Jurnal Sosial Humaniora, 6, No. 1 (2013): 62-75.

Sudjatmiko, Tomi. "Top Inovator Harus Tularkan Inovasinya”, KR Jogja, 19 Juli 2018,https://krjogja.com/web/news/read/72249/Top-Inovator-HarusTularkan_Inovasinya

Sugihartati, Rahma. Perkembangan Masyarakat Informasi \& Teori Sosial Kontemporer. Jakarta: Kencana, 2014.

Suharto, Edi. Analisis Kebijakan Publik. Bandung: CV Alfabeta, 2014

Suhendra, AS. "Kesiapan Pemerintah Daerah dalam Mewujudkan Kota Cerdas di Bandung dan Surabaya". Matra Pembaruan: Jurnal Inovasi Kebijakan 1, No. 1 (2017): 1-9. https://doi.org/10.21787/mp.1.1.2017.1-9

Surjani, P. "Manajemen Strategi Dalam Menghadapi Era Globalisasi”. Unitas 11. No. 1 (2002): 20-36.

Tachjan. Implementasi Kebijakan Publik. Bandung: AIPI, 2006. 
Rio Febriannur Rachman

Ulya, Husna Ni'matul. "Paradigma Kemiskinan Dalam Perspektif Islam Dan Konvensional". El Barka: Journal Economic and Business 1, No. 1 (2018): 90-113

Utomo, Sad Dian. "Partisipasi Masyarakat dalam Pembuatan Kebijakan" dalam Indra J. Piliang, Ramdani, Dendi dan Agung Pribadi, Otonomi Daerah: Evaluasi dan Proyeksi. Jakarta: Penerbit Divisi Kajian Demokrasi Lokal Yayasan Harkat Bangsa, 2003.

Winarno, Budi. Kebijakan Publik: Teori dan Proses. Yogyakarta: Med Press, 2007.

Yin, Robert K. Case Study Research: Design and Methods. London: Sage Publication, 2003. 